\title{
Leptin regulates sugar and amino acids transport in the human intestinal cell line Caco-2
}

Carmen Fanjul ${ }^{1}$, Jaione Barrenetxe ${ }^{1}$, Carmen Iñigo ${ }^{2}$, Yassine Sakar ${ }^{3}$, Robert Ducroc ${ }^{3}$, Ana Barber ${ }^{1}$, Maria Pilar Lostao ${ }^{1}$

${ }^{1}$ Department of Nutrition, Food Science, Physiology and Toxicology, University of Navarra, Pamplona, Spain.

${ }^{2}$ Department of Biochemistry, Miguel Servet Hospital, Zaragoza, Spain

${ }^{3}$ Institut National de la Santé et de la Recherche Médicale, U773, CRB3 Faculté de Médecine Xavier Bichat, Paris, France.

Corresponding author: Maria Pilar Lostao. Department of Nutrition, Food Science, Physiology and Toxicology. University of Navarra.31008 Pamplona, Spain. Email: plostao@unav.es. Telephone: 34-948425600. Fax: 34-948425649.

Short title: Leptin regulation of Caco-2 transporters 


\begin{abstract}
Aim: Studies in rodents have shown that leptin controls sugars and glutamine entry in the enterocytes by regulating membrane transporters. Here, we have examined the effect of leptin on sugar and amino acids absorption in the human model of intestinal cells Caco-2 and investigated the transporters involved.
\end{abstract}

Methods: Substrate uptake experiments were performed in Caco-2 cells, grown on plates, in the presence and the absence of leptin and the expression of the different transporters in brush border membrane vesicles was analysed by Western blot.

Results: Leptin inhibited $0.1 \mathrm{mM} \alpha$-methyl-D-glucoside uptake after 5 or $30 \mathrm{~min}$ treatment, and decreased SGLT1 protein abundance in the apical membrane. Uptake of $20 \mu \mathrm{M}$ glutamine and $0.1 \mathrm{mM}$ phenylalanine was also inhibited by leptin, indicating sensitivity to the hormone of the $\mathrm{Na}^{+}$-dependent neutral amino acid transporters ASCT2 and $\mathrm{B}^{0} \mathrm{AT} 1$. This inhibition was accompanied by a reduction of the transporters expression at the brush-border membrane. Leptin also inhibited $1 \mathrm{mM}$ proline and $\beta$ alanine uptake in $\mathrm{Na}^{+}$medium at $\mathrm{pH}$, conditions for optimal activity of the $\mathrm{H}^{+}-$ dependent neutral amino acid transporter PAT1. In this case, abundance of PAT1 in the brush-border membrane after leptin treatment was not modified. Interestingly, leptin inhibitory effect on $\beta$-alanine uptake was reversed by the PKA inhibitor H-89 suggesting involvement of PKA pathway in leptin's regulation of PAT1 activity.

Conclusion: These data show in human intestinal cells that leptin can rapidly control the activity of physiologically relevant transporters for rich-energy molecules, i.e Dglucose (SGLT1) and amino acids (ASCT2, $\mathrm{B}^{0} \mathrm{AT} 1$ and PAT1).

Keywords: amino acid transporters, Caco-2 cells, leptin, sodium-dependent glucose transporter 1 , western blot 


\section{INTRODUCTION}

Leptin was discovered in 1994 and described as an adipostatic signal controlling body weight and adiposity (Zhang et al. 1994). Nowadays, however, leptin is considered as a multifunctional hormone with many peripheral actions including immune function, bone development, growth and fertility (Gertler 2009). Accordingly, leptin production has been found in many different tissues in addition to adipose cells (Bado et al. 1998, Cammisotto et al. 2010, De Matteis et al. 2002, Martinez-Ansó et al. 1999) and leptin receptors are expressed ubiquitously in peripheral tissues (Gertler 2009, Margetic et al. 2002).

In the stomach, after a meal, leptin is secreted into the gastric lumen by pepsinogencontaining secretory granules of the chief cells (Bado et al. 1998, Cammisotto et al. 2005) together with the leptin soluble receptor which co-localizes in those secretory granules (Cammisotto et al. 2006). Leptin secretion from the gastric mucosa is also regulated by acetylcholine released by the vagus nerve, several hormones like secretin, CCK and insuline and the nutritional status of the body (Bado et al.1998; Cammisotto et al. 2010). Despite the low $\mathrm{pH}$ of the gastric juice, leptin remains stable and is able to reach the intestinal lumen because the binding to its soluble receptor protects it from degradation (Guilmeau et al. 2004).

In agreement with these data, we have demonstrated that leptin receptors are expressed in both the apical and basolateral membrane of the intestinal absorptive cells (Barrenetxe et al. 2002) indicating that the hormone can access the enterocytes from the blood and from the intestinal lumen. We have also shown in rodents using in vitro and in vivo techniques, that leptin inhibits the sugar active transporter SGLT1, acting from the luminal side (Barrenetxe et al. 2001, Ducroc et al. 2005, Iñigo et al. 2004, Iñigo et al. 2007, Lostao et al. 1998). This effect is mediated by PKA and PKC (Barrenetxe et 
al. 2004, Ducroc et al. 2005) and is reversible (Iñigo et al. 2007). Interestingly, luminal leptin increases peptide absorption in rat intestine in vivo and in Caco-2 cells acting from the apical membrane (Buyse et al. 2001), as well as butyrate uptake in the same cell line (Buyse et al. 2002). In addition, it has been recently demonstrated that luminal leptin also increases GLUT2 and GLUT5 insertion in the apical membrane of the rat enterocytes leading to an enhanced galactose and fructose absorption (Sakar et al. 2009). Finally, we recently showed in rat small intestine that leptin inhibits glutamine transport by regulating activity and gene expression of its transporters ASCT2 and $\mathrm{B}^{0} \mathrm{AT} 1$ (Ducroc et al. 2010).

Altogether, these observations support the view that gastric leptin can exert a regulatory role on intestinal nutrients absorption in the postprandial state. However, whether leptin can modulate sugars or amino acids absorption in human intestine is not documented. The purpose of the present study was therefore to extent our previous work and investigate in Caco-2 cells, a model of human intestinal epithelial cells, the effect of apical leptin on the absorption of sugars ( $\alpha$-methyl-glucoside; MG) and the amino acids glutamine (Gln), phenylalanine (Phe), $\beta$-alanine ( $\beta$-Ala) and Proline (Pro), and the transporters involved.

The results show that leptin regulates the uptake of $M G$ and Gln by down-regulating the traffic of the corresponding transporters SGLT1 (SLC5A1), ASCT2 (SLC1A5) and $\mathrm{B}^{0} \mathrm{AT} 1$ (SLC6A19) to the plasma membrane. Transport of Pro and $\beta$-Ala was also found reduced by leptin, as the result of a decreased activity of the proton-coupled amino acid transporter PAT1 (SLC36A1) via leptin activation of an $\mathrm{H}-89$ sensitive pathway.

\section{MATERIAL AND METHODS}

\section{Materials}


The Caco-2 cell line PD7 clone was kindly provided by Dr. Edith Brot-Laroche. The radiolabeled products $\left[{ }^{14} \mathrm{C}\right]-\alpha$-methyl-glucoside $\left(303 \mathrm{mCi} \mathrm{ml}^{-1}\right), \mathrm{L}-\left[2,3-{ }^{3} \mathrm{H}\right]$-proline (40 $\left.\mathrm{Ci} \mathrm{ml}{ }^{-1}\right), \mathrm{L}-\left[3,4-{ }^{3} \mathrm{H}\right]$-glutamine $\left(30 \mathrm{Ci} \mathrm{ml}^{-1}\right)$ and $\mathrm{L}-\left[3,4-{ }^{3} \mathrm{H}\right]$-phenylalanine $\left(30 \mathrm{Ci} \mathrm{ml}^{-1}\right)$ were purchased from Perkin Elmer Inc. (Life Sciences, Boston, MA, USA) and $\beta-[3-$ ${ }^{3} \mathrm{H}$--alanine $\left(50 \mathrm{Ci} \mathrm{ml}^{-1}\right.$ ) from American Radiolabeled Chemicals Inc (St Louis, MO, USA). All unlabeled amino acids and $\alpha$-methyl-glucoside, were obtained from Sigma Chemicals Inc (St Louis, MO, USA) and human leptin from Peprotech Inc (UK).

Cell culture

Caco-2 cells were maintained in a humidified atmosphere of $5 \% \mathrm{CO}_{2}-95 \%$ at $37^{\circ} \mathrm{C}$. Cells (passages 50-70) were grown in Dulbecco's Modified Eagles medium (DMEM) (Gibco Invitrogen, Paisley, UK) supplemented with 10\% fetal bovine serum (FBS), 1\% non essential amino acids, $1 \%$ penicillin $\left(1000 \mathrm{U} \mathrm{ml}^{-1}\right), 1 \%$ streptomycin $\left(1000 \mu \mathrm{g} \mathrm{ml}^{-1}\right)$ and $1 \%$ amphoterycin $\left(250 \mathrm{U} \mathrm{ml}^{-1}\right)$. Once the cells reached $80 \%$ confluence, they were dissociated with $0.05 \%$ trypsin-EDTA and sub-cultured on 25 or $75 \mathrm{~cm}^{2}$ plastic flasks at a density of $25 \times 10^{4}$ cells cm$~_{-2}$. For transport studies, the cells were seeded at a $6 \times 10^{4}$ cells $\mathrm{cm}^{-2}$ density in 24 well culture plates. Culture medium was replaced every 2 days. Cell confluence was confirmed by microscopic observance. Experiments were performed 17-21 days post-seeding.

\section{Uptake measurements}

For sugar assays, cells were pre-incubated in serum and glucose-free DMEM, $2 \mathrm{~h}$ before the beginning of the experiment. In this medium, used as uptake buffer, $0.1 \mathrm{mM} \mathrm{MG}$ (SGLT1 specific substrate) was diluted with traces of ${ }^{14} \mathrm{C} \mathrm{MG}\left(0.3 \mu \mathrm{Ci} \mathrm{ml}{ }^{-1}\right)$. For amino acid uptake assays, all the different amino acids $(0.1 \mathrm{mM}$ and $20 \mu \mathrm{M}$ Gln, $0.1 \mathrm{mM}$ Phe, $1 \mathrm{mM} \beta$-Ala and Pro) with traces of their respective radiolabeled substrates $\left(2 \mu \mathrm{Ci} \mathrm{ml}^{-1}\right)$ were diluted in Krebs modified buffer (also referred as $\mathrm{Na}^{+}$medium): $5.4 \mathrm{mM} \mathrm{KCl}, 2.8$ 
$\mathrm{mM} \mathrm{CaCl}_{2}, 1 \mathrm{mM} \mathrm{MgSO}$, $0.3 \mathrm{mM} \mathrm{NaH} \mathrm{PO}_{4}, 137 \mathrm{mM} \mathrm{NaCl}, 0.3 \mathrm{mM} \mathrm{KH} \mathrm{PO}_{4}, 10$ $\mathrm{mM}$ glucose and $10 \mathrm{mM}$ HEPES/Tris $(\mathrm{pH} 7.5)$ or Mes/Tris $(\mathrm{pH}$ 6). To check if the presence of glutamine in the incubation medium could modify the uptake of the amino acid, cells were incubated for $2 \mathrm{~h}$ in the absence of glutamine. The results obtained were similar to those in which the cells had been incubated with glutamine until the beginning of the experiment. Therefore, glutamine was present routinely in the incubation medium. In the experiments performed in $\mathrm{Na}^{+}$-free medium, $\mathrm{NaCl}$ was replaced with choline chloride.

A similar protocol for MG and amino acids uptake assays was followed. Cells were gently washed with substrate free medium and uptake was initiated by adding $0.5 \mathrm{ml}$ uptake buffer in the absence or presence of 0.2 or $8 \mathrm{nM}$ human leptin. These leptin concentrations were chosen because they correspond to the leptin plasma levels in normal and obese individuals respectively and were used in our previous works (Heinonen et al. 2005, Lostao et al. 1998). In the experiments in which the PKA inhibitor H-89 (Calbiochem, Nottingham, UK) was used, a set of cells were preincubated for $30 \mathrm{~min}$ with the corresponding uptake buffer containing $1 \mu \mathrm{M} \mathrm{H}-89$, before the addition of the substrate uptake solution with or without leptin that also contained H-89. In these studies, another set of cells where preincubated for the same time with the corresponding uptake buffer without $\mathrm{H}-89$ before measuring the substrate uptake. After an incubation period of 5 or $30 \mathrm{~min}$ at $37^{\circ} \mathrm{C}$, uptake was stopped with ice cold free-substrate buffer followed by aspiration. Cells were again washed twice with ice-cold buffer to eliminate non-specific radioactivity fixation and were finally solubilized in $500 \mu 1$ 1\% Triton X-100 in $0.1 \mathrm{~N} \mathrm{NaOH}$. Samples (100 $\mu 1)$ were taken to measure radioactivity by liquid scintillation counting. Protein concentration was 
determined by Bradford method (Bio-Rad Protein Assay, Bio-Rad laboratories, Hercules, CA).

All the uptake experiments were performed in cell monolayers grown on culture plates. Repetition of some of these studies on cell monolayers grown on permeable membrane filters showed the same effect of leptin indicating that the support did not affect the expression of the nutrient's transporters or leptin receptor.

\section{Western blot analysis}

Cells grown on $75 \mathrm{~cm}^{2}$ plastic flasks were incubated for $30 \mathrm{~min}$ in the presence of 0.1 $\mathrm{mM}$ MG, Gln or $1 \mathrm{mM} \beta$-Ala with or without $8 \mathrm{nM}$ leptin. After the incubation period, brush-border membrane vesicles (BBMV) were isolated from each flask by $\mathrm{MgCl}_{2}$ precipitation method (Garriga et al. 1999, Shirazy-Beechey et al. 1990). The protein content of the vesicles was determined by the Bradford method (Bio-Rad Protein Assay, Bio-Rad laboratories, Hercules, CA). Alkaline phosphatase enrichment of the vesicles was determined by Cobas Mira S auto analyser (Roche Diagnostics, Frenchs Forests, NSW, Australia) and was 2.5-3 fold higher than the cells homogenate.

Solubilized proteins $(20 \mu \mathrm{g})$ were then resolved by electrophoresis on $12 \%$ SDS-PAGE mini gels. The resolved proteins were transferred to a PVDF membrane (Hybond P, GE Healthcare) and after blocking in TBS buffer with 3\% of BSA for three hours at room temperature (RT), subjected to immunoblot analysis with different primary antibodies overnight at $4^{\circ} \mathrm{C}$. The antibodies, used at 1:1,000, were the following: anti-SGLT1 antibody (generous gift from Ernest M. Wright) (Lostao et al. 1995); anti-B ${ }^{0}$ AT1 (generous gift from François Verrey) (Romeo et al. 2006); anti-ASCT2 antibody (Santa Cruz Biotech.). A polyclonal anti-PAT1 antibody raised against residues 107-119 of human PAT1 (Abyntek, Spain) was used at 1:200 dilution. After the incubation with the different antibodies, the membranes were washed three times in TBS-Tween $0.15 \%$ and 
incubated one hour at RT with the corresponding peroxidase conjugated secondary antibody (Santa Cruz Biotech.). The immunoreactive bands corresponding to PAT-1 disappeared after pre-incubation of the primary antibody with its corresponding control peptide, indicating its specificity.

Membranes were stripped and immunoblotted again with a monoclonal $\beta$-actin antibody (Santa Cruz Biotech.) used at 1:1,000, in order to perform the loading control of the different wells. The immunoreactive bands were detected by enhanced chemiluminiscence (Super Signal West Dura, Thermo Scientific) and quantified by densitometric analysis (Gel Pro Analyser 3.2). The results are expressed as the ratio protein content $/ \beta$-actin in $\%$ in relation to the corresponding control value which was arbitrarily set to 100 .

Statistical analysis

Results of transport experiments are expressed as $\mathrm{nmol} \mathrm{mg}^{-1}$ of protein. All data are presented as $\%$ compared to controls which are normalized at $100 \%$. Statistical differences were evaluated by the two-way ANOVA test or the one-way ANOVA test followed by the Dunnett post-hoc test or Student $t$-test for parametric analysis and $U$ Mann-Whitney test for non-parametric one. Differences were considered as statistically significant at $\mathrm{p}<0.05$. The calculations were performed using the SPSS/WINDOWS VERSION 15.0 statistical package (SPSS. Chicago, IL, USA)

\section{RESULTS}

Leptin inhibits a-methyl-glucoside (MG) uptake

The effect of $0.2 \mathrm{nM}$ and $8 \mathrm{nM}$ leptin on $0.1 \mathrm{mM}$ MG uptake was measured after 5 and $30 \mathrm{~min}$ incubation. MG uptake after $5 \mathrm{~min}$ in the absence of leptin (control value) ranged from 0.20 to $0.47 \mathrm{nmol} \mathrm{mg}^{-1}$ of protein, whereas after $30 \mathrm{~min}$ it ranged from 0.93 to $1.37 \mathrm{nmol} \mathrm{mg}^{-1}$ of protein. As shown in Fig.1a, leptin inhibited by $\sim 25-30 \%$ the sugar 
uptake at both concentrations. This effect was statistically significant at $5 \mathrm{~min}$, while at 30 min only the highest concentration of leptin was able to significantly reduce the sugar uptake. Under this condition (30 min incubation with $8 \mathrm{nM}$ leptin) this effect was accompanied by a decrease on the amount of SGLT1 (75 kDa) (Lostao et al. 1995) in the BBMV of Caco-2 cells.

We previously demonstrated that PKA is involved in the inhibitory effect of leptin on intestinal sugar transport in rat (Barrenetxe et al. 2004). We therefore investigated whether a PKA-dependent pathway could also be implicated in leptin inhibition of sugar transport in Caco-2 cells. The uptake of $0.1 \mathrm{mM} \mathrm{MG}$ was measured in the presence of $8 \mathrm{nM}$ leptin with and without pre-incubation of the cells for 30 min with the PKA inhibitor H-89. The results showed that H-89 did not modify MG uptake neither in the absence nor in the presence of leptin, indicating that the action of the hormone is not mediated by PKA.

Leptin inhibits amino acids uptake

The effect of leptin on glutamine uptake was also analysed under the same conditions as MG. After 5 min incubation, 0.2 and $8 \mathrm{nM}$ leptin reduced $0.1 \mathrm{mM}$ Gln uptake by $\sim 30 \%$ and $\sim 50 \%$ respectively. At $30 \mathrm{~min}$, the inhibition was similar ( $\sim 30 \%)$ for both hormone concentrations (Fig 2A). In these experiments, Gln uptake values in the absence of leptin at $5 \mathrm{~min}$ ranged from 1.04 to $1.50 \mathrm{nmol} \mathrm{mg}^{-1}$ protein, and at $30 \mathrm{~min}$ from 2.17 to $4.09 \mathrm{nmol} \mathrm{mg}^{-1}$ of protein.

The intestinal transport of Gln from the apical membrane of the enterocytes is mainly mediated by two $\mathrm{Na}^{+}$-dependent transporters: $\mathrm{B}^{0} \mathrm{AT} 1$ (SLC6A19), with a $\mathrm{K}_{0.5}$ of $0.6-4$ $\mathrm{mM}$, and ASCT2 (SLC1A5) with a $\mathrm{K}_{0.5}$ of $\sim 20 \mu \mathrm{M}[7,8,38,41]$ and only weakly by the apical $\mathrm{Na}^{+}$-independent heterodimeric transporter $\mathrm{rBAT} / \mathrm{b}^{0,+} \mathrm{AT}$ (SLC31A1/SLC7A9) with a $\mathrm{K}_{\mathrm{i}}$ of $\sim 400 \mu \mathrm{M}$ (Broer 2008, Rajan et al. 2000). To 
investigate which of the Gln transporters could be implicated in the reduction of the amino acid uptake by leptin, we studied the uptake of Gln at the concentration of $20 \mu \mathrm{M}$ after $30 \mathrm{~min}$ (control values ranged from 0.49 to $0.54 \mathrm{nmol} \mathrm{mg}^{-1}$ of protein) in the presence of $8 \mathrm{nM}$ leptin or $25 \mathrm{mM}$ Phe, since Phe can not be transported by ASCT2 but is a specific substrate of $\mathrm{B}^{0} \mathrm{AT} 1$ (Broer 2008). As shown in Fig. 2b, Phe did not inhibit Gln uptake indicating that $\mathrm{B}^{0} \mathrm{AT} 1$ was not contributing to the amino acid transport. Nevertheless, leptin reduced by $20 \%$ the Phe-insensitive uptake of Gln, indicating that ASCT2 is inhibited by the hormone. Uptake of $0.1 \mathrm{mM}$ Phe $\left(\mathrm{B}^{0} \mathrm{AT} 1\right.$-mediated transport) was also measured in the presence of 0.2 and $8 \mathrm{nM}$ leptin at 5 and $30 \mathrm{~min}$ (Fig. 2c). Phe uptake in control conditions was lower than that observed with $0.1 \mathrm{mM}$ Gln: values ranged from 0.46 to $0.74 \mathrm{nmol} \mathrm{mg}^{-1}$ of protein at $5 \mathrm{~min}$ and from 1.94 to $3.01 \mathrm{nmol} \mathrm{mg} \mathrm{m}^{-1}$ of protein at $30 \mathrm{~min}$. Phe uptake was also inhibited by leptin, although with less potency than Gln uptake (Fig. 2c), demonstrating the sensitivity of $\mathrm{B}^{0} \mathrm{AT} 1$ to the hormone. In order to investigate the relative contribution of the $\mathrm{Na}^{+}$-independent transporter $\mathrm{rBAT} / \mathrm{b}^{0,+} \mathrm{AT}$ on Gln uptake and its possible regulation by leptin, we studied the uptake of $0.1 \mathrm{mM} \mathrm{Gln}$ after $30 \mathrm{~min}$, in the presence and in the absence of $8 \mathrm{nM}$ leptin in $\mathrm{Na}^{+}$and $\mathrm{Na}^{+}$-free medium. In the absence of $\mathrm{Na}^{+}$, Gln uptake was reduced by $80 \%$ and was not affected by leptin, indicating minimal participation of $\mathrm{rBAT} / \mathrm{b}^{0,+} \mathrm{AT}$ in Gln uptake in Caco-2 cells and unsensitivity to the hormone (Fig. 2d).

The expression of $\mathrm{B}^{0} \mathrm{AT} 1$ and $\mathrm{ASCT} 2$ in Caco- 2 BBMV in the presence and the absence of leptin was then analysed by Western blot (Fig 3). As occurred with SGLT1, leptin decreased the expression of both $\mathrm{B}^{0} \mathrm{AT} 1(\sim 60 \mathrm{kDa})$ (Romeo et al. 2006) and ASCT2 ( $\sim 60 \mathrm{kDa})$ (Nose et al. 2010) in BBMV compared with their expression in control condition, in line with the reduced uptake of Gln observed in the transport experiments. As for the sugar uptake experiments, we analysed the possible implication 
of PKA in the leptin regulation of Gln uptake. Figure $3 b$ shows that pre-incubation of the cells with H-89 did not affect basal uptake of $0.1 \mathrm{mM}$ Gln. However, H-89 enhanced the inhibitory effect of leptin on Gln uptake suggesting the involvement of a PKA-dependent pathway in leptin action.

PAT1 (SLC36A1) is responsible for the $\mathrm{H}^{+}$-coupled amino acid transport through the apical membrane of Caco-2 cells (Chen et al. 2003). In order to investigate whether this transporter could be also regulated by leptin, we first checked its functional presence in the Caco-2 PD7 clone. Uptake of $1 \mathrm{mM}$ proline $(30 \mathrm{~min})$ in the presence of $\mathrm{Na}^{+}$ increased by $\sim 20 \%$ compared with the uptake in the absence of $\mathrm{Na}^{+}$(Fig. $4 \mathrm{a}$ ). When the medium $\mathrm{pH}$ decreased from 7.5 to 6 , Pro uptake increased by 1.6 and 1.7 fold in the absence and in the presence of $\mathrm{Na}^{+}$respectively, being the highest in the presence of $\mathrm{Na}^{+}$ at $\mathrm{pH} 6$ (Fig. 4a) and indicating PAT1 activity in this Caco-2 clone. We thus investigated the effect of 0.2 and $8 \mathrm{nM}$ leptin on the uptake of $1 \mathrm{mM}$ Pro and $\beta$-Ala (a PAT1 but not $\mathrm{B}^{0} \mathrm{AT} 1$ substrate) (Broer 2008), at $\mathrm{pH} 6$ in the presence of $\mathrm{Na}^{+}$after 5 and 30 min incubation. As shown in Fig. 4b, leptin inhibited Pro transport at 5 and 30 min, with a higher effect at $5 \min (\sim 35 \%$ vs $\sim 15-20 \%)$. Likewise, uptake of $\beta$-Ala was also reduced ( $\sim 40-50 \%)$ by the two hormone concentrations assayed and at the two incubation times (Fig. 4c). These results suggested that PAT1 activity is also regulated by leptin. However, Western blot assays showed that the expression of PAT1 $(\sim 55 \mathrm{kDa})$ (Dorn et al. 2009) in the BBMV was not modified by the hormone. (Fig. 5a) Because amino acid uptake via human PAT1 in Caco- 2 cells is inhibited by activators of the cAMP pathway through inhibition of the $\mathrm{Na}^{+} / \mathrm{H}^{+}$exchanger 3 (NHE3) activity (Anderson et al. 2005) and the mechanism of inhibition of $\beta$-Ala uptake by leptin did not seem to involve decrease of PAT1 abundance in BBMV, we decided to investigate whether a PKA-dependent pathway could be implicated in this leptin effect. The uptake 
of $1 \mathrm{mM} \beta$-Ala was measured in $\mathrm{Na}^{+}$medium at $\mathrm{pH} 6$ in the presence of $8 \mathrm{nM}$ leptin in control conditions and after pre-incubation of the cells with $1 \mu \mathrm{M} \mathrm{H}-89$. As shown in Fig. 5b, H-89 did not modify $\beta$-Ala uptake, but clearly blocked the inhibitory effect of leptin on $\beta$-Ala uptake indicating PKA involvement. To check the possible participation of NHE3 on leptin inhibition of $\beta$-Ala uptake, we measured the effect of $8 \mathrm{nM}$ leptin on $1 \mathrm{mM} \beta$-Ala uptake at $\mathrm{pH} 6$ in both, $\mathrm{Na}^{+}$and $\mathrm{Na}^{+}$- free medium, condition in which the activity of NHE3 is annulled. As it is shown in figure $5 \mathrm{c}$, in the absence of $\mathrm{Na}^{+}$there was a reduction on $\beta$-Ala uptake, similar to that for Pro shown in figure $4 \mathrm{a}$, that was not modified by leptin, indicating that the hormone inhibition of $\beta$-Ala uptake is $\mathrm{Na}^{+}-$ dependent and may require NHE3 activity.

\section{DISCUSSION}

The present work enlarges previous data about leptin regulation of intestinal nutrient absorption by demonstrating in the human intestinal cell line Caco-2 that leptin, acting from the apical membrane, can rapidly inhibit sugar and amino acids uptake. This inhibition is accompanied by a decrease in the amount of SGLT1, $\mathrm{B}^{0} \mathrm{AT} 1$ and ASCT2 proteins in the brush border membrane of the cells but not of PAT1.

These results are in line with previous studies from our laboratory that have extensively demonstrated in rodents, in vitro and in vivo, the fast inhibitory effect of luminal leptin on sugar absorption, already observed after 2-3 min incubation with the hormone (Barrenetxe et al. 2001, Ducroc et al. 2005, Iñigo et al. 2004, Iñigo et al. 2007, Lostao et al. 1998, Sakar et al. 2009) and the decrease in the abundance of the $\mathrm{Na}^{+}$-glucose cotransporter SGLT1 protein in the brush border membrane (Ducroc et al. 2005). These observations on murine intestine are now confirmed in the Caco-2 cell line, a model of human intestinal epithelium, in which the presence of leptin receptors is well 
documented (Buyse et al. 2001). Here, apical leptin inhibits MG uptake after a short incubation period, and this inhibition is accompanied by a decrease in the amount of SGLT1 in the apical membrane of the cells. In contrast to the studies in rat (Barrenetxe et al. 2004), in Caco-2 cells, this effect is not PKA-dependent.

In continuation with our studies, we recently demonstrated in rat, a short-term downregulation by luminal leptin of two of the $\mathrm{Na}^{+}$-dependent transporters involved in $\mathrm{Gln}$ absorption: ASCT2 and $\mathrm{B}^{0} \mathrm{AT} 1$ (Ducroc et al. 2010). In Caco-2 cells, the expression of ASCT2 has been demonstrated (Nose et al. 2010) and the presence of a $\mathrm{Na}^{+}$-dependent Gln transport system ascribed to system B has been described (Souba et al. 1992) although its molecular identity has not been identified yet. Here, we demonstrate functionally and biochemically in the Caco- 2 cell line that both ASCT2 and $\mathrm{B}^{0} \mathrm{AT} 1$ are present and regulated by leptin. Moreover, we show that a PKA-dependent intracellular pathway is involved in leptin inhibition of Gln uptake. Since ASCT2 exhibits a micromolar $\mathrm{K}_{0.5}$ for Gln (Utsunomiya-Tate et al. 1996) whereas $\mathrm{B}^{0} \mathrm{AT} 1 \mathrm{~K}_{0.5}$ is $\sim 0.6-4$ mM (Broer et al. 2004, Broer 2008) we performed competition experiments to discriminate between these transporters. As previously reported in rat (Ducroc et al. 2010), uptake of $20 \mu \mathrm{M}$ Gln was not inhibited by $25 \mathrm{mM}$ Phe, a specific substrate of $\mathrm{B}^{0} \mathrm{AT} 1$, indicating that the high affinity transporter ASCT2 is responsible for Gln uptake at that concentration. Since this transport can be decreased by leptin, it shows that ASCT2 is present in Caco-2 cells and is regulated by the hormone. Furthermore, direct measurement of ASCT2 protein, achieved by Western blot analysis, indicated that in the presence of Gln, leptin decreased the amount of ASCT2 in BBMV, as previously found in rat intestine (Ducroc et al. 2010). Uptake of $0.1 \mathrm{mM}$ Phe, which is mainly mediated by $\mathrm{B}^{0} \mathrm{AT} 1$ (Broer 2008), was also inhibited by leptin, which decreased $\mathrm{B}^{0} \mathrm{AT} 1$ abundance in BBMV as well. As it has been reported in rat intestine (Ducroc et al. 
2010), the lower control uptake values for $0.1 \mathrm{mM}$ Phe compared with the control uptake values for $0.1 \mathrm{mM}$ Gln, would be explained by the lower affinity of $\mathrm{B}^{0} \mathrm{AT} 1$ compared with ASCT2 [Broer et al. 2004, Broer 2008, Utsunomiya-Tate et al. 1996). Altogether these data confirm in the human model of epithelial intestinal cells the results found in rat intestine and demonstrate for the first time the expression of $\mathrm{B}^{0} \mathrm{AT} 1$ protein in these cells.

Caco-2 cell line also expresses the $\mathrm{H}^{+}$-dependent Pro and $\beta$-Ala transporter PAT1 (Anderson et al. 2004, Chen et al. 2003, Thwaites et al. 1993) and it has been suggested that in differentiated Caco-2 cells, PAT1 is the major transporter for Pro (Metzner et al. 2004). Here, we confirm the implication of PAT1 in the intestinal uptake of Pro, as the acidification of the medium significantly stimulated the uptake of the amino acid in the presence and the absence of $\mathrm{Na}^{+}$.

The cooperative functional relationship between PAT1 and the $\mathrm{Na}^{+} / \mathrm{H}^{+}$exchanger NHE3 (Anderson et al. 2004) could explain the $\mathrm{Na}^{+}$dependence of Pro uptake herein found and previously observed in rat intestine (Iñigo et al. 2006). It is noteworthy that the assays to determine leptin effect on Pro and $\beta$-Ala uptake were performed in the presence of $\mathrm{Na}^{+}$and $\mathrm{pH}$ 6. Leptin inhibited Pro and $\beta$-Ala uptake demonstrating the inhibitory effect of the hormone on PAT1 transporter in the Caco-2 cell line. The Western blot experiments, however, did not show reduction of PAT1 abundance in the apical membrane of the cells after treatment with the hormone. As previously mentioned, activity of the apical $\mathrm{Na}^{+} / \mathrm{H}^{+}$exchanger maintains the $\mathrm{H}^{+}$electrochemical gradient necessary for the correct functionality of PAT1 (Anderson et al. 2004, Seidler et al. 2008). Moreover, it has been demonstrated that activation of cAMP/PKA pathway decreases the activity of the $\mathrm{Na}^{+} / \mathrm{H}^{+}$exchanger NHE3 (Anderson \& Thwaites 2005) and indirectly inhibits PAT1, in line with the fact that PAT1 has no intracellular PKA 
phosphorylation sites (Chen et al. 2004). On the other hand, it is well known that leptin is able to activate PKA (Barrenetxe et al. 2004, Than et al. 2011). Our results with H-89 are in accordance with these data since we show the implication of PKA in leptin inhibition of $\beta$-Ala uptake and that leptin does not exert its inhibitory effect in the absence of sodium when the $\mathrm{Na}^{+} / \mathrm{H}^{+}$exchanger activity is blunted. Interestingly, it has been demonstrated that NHE1 activity is regulated by leptin in erythrocytes where leptin receptors are expressed (Konstantinou-Tegou et al. 2001), which support that the $\mathrm{Na}^{+} / \mathrm{H}^{+}$exchangers are leptin targets. Therefore, we suggest that leptin would alter the activity of the $\mathrm{Na}^{+} / \mathrm{H}^{+}$exchanger with the corresponding decrease in the $\mathrm{H}^{+}$gradient, PAT1 activity and final reduction of Pro and $\beta$-Ala uptake. Therefore, we suggest that the primary action of leptin would be the inhibition of NHE3 activity with the corresponding decrease in the $\mathrm{H}^{+}$gradient, PAT1 activity and finally a reduction of Pro and $\beta$-Ala uptake.

It has been reported in monolayer of Caco-2 cells grown and differentiated on permeable supports that luminal leptin produces, after $30 \mathrm{~min}$ incubation, an increase in both uptake of dipeptides by the $\mathrm{H}^{+}$-dependent transporter PEPT1 and translocation of the transporter from the intracellular pool to the plasma membrane (Buyse et al. 2001). In the case of PEPT1 and under those experimental conditions, it is possible that, besides the inhibitory effect on NHE3 activity, leptin could up-regulate PEPT1 expression in the plasma membrane, which would overcome the effect on dipeptides uptake related to a reduction of the $\mathrm{H}^{+}$gradient.

Leptin also enhances CD147/MCT-1 mediated uptake of butyrate but, in this case, the effect requires at least $12 \mathrm{~h}$ and is due to increase in the intracellular pool of MCT-1 and translocation of CD147/MCT-1 to the apical plasma membrane (Buyse et al. 2002). 
In summary, leptin modulates sugar and amino acid uptake in human Caco-2 cell line in a short-term manner, in line with its physiological role as gastric delivered hormone acting on epithelial cells of the small intestine. The present results together with previous data from the literature show that leptin regulation of nutrients absorption is fast (occurring already at $5 \mathrm{~min}$ ); is reversible (Iñigo et al. 2007); produces increase or decrease on the absorption which is around $35 \%$ of the control values and never higher that 50\%; affects various nutrients including sugars (Barrenetxe et al. 2001, Ducroc et al. 2005, Lostao et al. 1998, Sakar et al. 2009) amino acids (Ducroc et al. 2010) peptides (Buyse et al. 2001) and short chain fatty acids (Buyse et al. 2002); and in most cases involves the recruitment or insertion of the corresponding transporters into the apical membrane of the enterocytes (Buyse et al. 2001, Ducroc et al. 2005, Ducroc et al. 2010). Therefore, leptin is a major physiological molecule which participates in the modulation of nutrients absorption adjusting their entry into the enterocytes according to its needs.

\section{Acknowledgments}

We thank Asunción Redín for its unconditional technical assistance.

This work was supported by "Ministerio de Educación y Ciencia", Spain (Grant BFU 2007 60420/BFI) and "Fundación Marcelino Botín". The Spanish group is member of the Network for Cooperative Research on Membrane Transport Proteins (REIT), cofunded by the "Ministerio de Educación y Ciencia", Spain and the European Regional Development Fund (ERDF) (Grant BFU2007-30688-E/BFI). C. Fanjul is a recipient of a fellowship from "Asociación de Amigos", University of Navarra. Y. Sakar is a recipient of a fellowship from "Foundation pour la Recherche Médicale" 


\section{Disclosures}

No conflicts of interest, financial or otherwise, are declared by the authors. 


\section{REFERENCES}

Anderson, C. M., Grenade, D. S., Boll, M., Foltz, M., Wake, K. A., Kennedy, D. J., Munck, L. K., Miyauchi, S., Taylor, P. M., Campbell, F. C., Munck, B. G., Daniel, H., Ganapathy, V. \& Thwaites, D. T. 2004. $\mathrm{H}^{+} /$amino acid transporter 1 (PAT1) is the imino acid carrier: An intestinal nutrient/drug transporter in human and rat. Gastroenterology 127, 1410-22.

Anderson, C. M. \& Thwaites, D. T. 2005. Indirect regulation of the intestinal $\mathrm{H}^{+}$coupled amino acid transporter hPAT1 (SLC36A1). J Cell Physio. 204, 604-13.

Bado, A., Levasseur, S., Attoub, S., Kermorgant, S., Laigneau, J. P., Bortoluzzi, M. N., Moizo, L., Lehy, T., Guerre-Millo, M., Le Marchand-Brustel, Y. \& Lewin, M. J. 1998. The stomach is a source of leptin. Nature 394, 790-3.

Barrenetxe, J., Barber, A. \& Lostao, M. P. 2001. Leptin effect on galactose absorption in mice jejunum, $J$ Physiol Biochem 57, 345-6.

Barrenetxe, J., Villaro, A. C., Guembe, L., Pascual, I., Munoz-Navas, M., Barber, A. \& Lostao, M. P. 2002. Distribution of the long leptin receptor isoform in brush border, basolateral membrane, and cytoplasm of enterocytes. Gut. 50, 797-802.

Barrenetxe, J., Sainz, N., Barber, A. \& Lostao, M. P. 2004. Involvement of PKC and PKA in the inhibitory effect of leptin on intestinal galactose absorption. Biochem Biophys Res Commun 317, 717-21.

Broer, A., Klingel, K., Kowalczuk, S., Rasko, J. E., Cavanaugh, J. \& Broer, S. 2004. Molecular cloning of mouse amino acid transport system $\mathrm{B}^{0}$, a neutral amino acid transporter related to Hartnup disorder, J Biol Chem 279, 24467-76.

Broer, S. 2008. Amino acid transport across mammalian intestinal and renal epithelia. Physiol Rev 88, 249-86. 
Buyse, M., Berlioz, F., Guilmeau, S., Tsocas, A., Voisin, T., Peranzi, G., Merlin, D., Laburthe, M., Lewin, M. J., Roze, C. \& Bado, A. 2001. PepT1-mediated epithelial transport of dipeptides and cephalexin is enhanced by luminal leptin in the small intestine, J Clin Invest 108, 1483-94.

Buyse, M., Sitaraman, S. V., Liu, X., Bado, A. \& Merlin, D. 2002. Luminal leptin enhances CD147/MCT-1-mediated uptake of butyrate in the human intestinal cell line Caco2-BBE. J Biol Chem 277, 28182-90.

Cammisotto, P. G., Renaud, C., Gingras, D., Delvin, E., Levy, E. \& Bendayan, M. 2005 Endocrine and exocrine secretion of leptin by the gastric mucosa. J Histochem Cytochem 53, 851-60.

Cammisotto, P. G., Gingras, D., Renaud, C., Levy, E. \& Bendayan, M. 2006. Secretion of soluble leptin receptors by exocrine and endocrine cells of the gastric mucosa. Am J Physiol Gastrointest Liver Physiol 290, G242-9.

Cammisotto, P. G., Levy, E., Bukowiecki, L. J. \& Bendayan, M. 2010. Cross-talk between adipose and gastric leptins for the control of food intake and energy metabolism. Prog Histochem Cytochem 45, 143-200.

Chen, Z., Fei, Y. J., Anderson, C. M., Wake, K. A., Miyauchi, S., Huang, W., Thwaites, D. T. \& Ganapathy, V. 2003. Structure, function and immunolocalization of a proton-coupled amino acid transporter (hPAT1) in the human intestinal cell line Caco-2. J Physiol 546, 349-61.

De Matteis, R., Puxeddu, R., Riva, A. \& Cinti, S. 2002. Intralobular ducts of human major salivary glands contain leptin and its receptor. J Anat 201, 363-70.

Dorn, M., Jaehme, M., Weiwad, M., Markwardt, F., Rudolph, R., Brandsch, M. \& Bosse-Doenecke, E. 2009. The role of N-glycosylation in transport function and surface targeting of the human solute carrier PAT1. FEBS Lett 583, 1631-6. 
Ducroc, R., Guilmeau, S., Akasbi, K., Devaud, H., Buyse, M. \& Bado, A. 2005. Luminal leptin induces rapid inhibition of active intestinal absorption of glucose mediated by sodium-glucose cotransporter 1 . Diabetes $54,348-54$.

Ducroc, R., Sakar, Y., Fanjul, C., Barber, A., Bado, A. \& Lostao, M. P. 2010. Luminal leptin inhibits L-glutamine transport in rat small intestine: involvement of ASCT2 and B0AT1. Am J Physiol Gastrointest Liver Physiol 299, G179-85.

Garriga, C., Rovira, N., Moretó, M. \& Planas, J. M. 1999. Expression of $\mathrm{Na}^{+}-\mathrm{D}$-glucose cotransporter in brush-border membrane of the chicken intestine. Am J Physiol 276, R627-31.

Gertler, A. 2009. Leptin and Leptin antagonists, Landes Bioscience.

Guilmeau, S., Buyse, M. \& Bado, A. 2004. Gastric leptin: a new manager of gastrointestinal function. Curr Opin Pharmacol 4, 561-6.

Heinonen, M. V., Purhonen, A. K., Miettinen, P., Paakkonen, M., Pirinen, E., Alhava, E., Akerman, K. \& Herzig, K. H. 2005. Apelin, orexin-A and leptin plasma levels in morbid obesity and effect of gastric banding. Regul Pept 130, 7-13.

Iñigo, C., Barber, A. \& Lostao, M. P. 2004. Leptin effect on intestinal galactose absorption in ob/ob and db/db mice. J Physiol Biochem 60, 93-7.

Iñigo, C., Barber, A. \& Lostao, M. P. $2006 \mathrm{Na}^{+}$and pH dependence of proline and betaalanine absorption in rat small intestine, Acta Physiol 186, 271-8.

Iñigo, C., Patel, N., Kellett, G. L., Barber, A. \& Lostao, M. P. 2007. Luminal leptin inhibits intestinal sugar absorption in vivo. Acta Physiol 190, 303-10.

Konstantinou-Tegou, A., Kaloyianni, M., Bourikas, D. \& Koliakos, G. 2001. The effect of leptin on $\mathrm{Na}^{+}-\mathrm{H}^{+}$antiport (NHE1) activity of obese and normal subjects erythrocytes. Mol Cell Endocrinol 183, 11-8. 
Lostao, M. P., Hirayama, B. A., Panayotova-Heiermann, M., Sampogna, S. L., Bok, D. \& Wright, E. M. 1995. Arginine-427 in the Na+/glucose cotransporter (SGLT1) is involved in trafficking to the plasma membrane. FEBS Lett 377, 181-4.

Lostao, M. P., Urdaneta, E., Martinez-Anso, E., Barber, A. \& Martinez, J. A. 1998. Presence of leptin receptors in rat small intestine and leptin effect on sugar absorption. FEBS Lett 423, 302-6.

Margetic, S., Gazzola, C., Pegg, G. G. \& Hill, R. A. 2002. Leptin: a review of its peripheral actions and interactions. Int J Obes Relat Metab Disord 26, 1407-33.

Martinez-Ansó, E., Lostao, M. P. \& Martinez, J. A. 1999. Immunohistochemical localization of leptin in rat kidney, Kidney Int 55, 1129-30.

Metzner, L., Kalbitz, J. \& Brandsch, M. 2004. Transport of pharmacologically active proline derivatives by the human proton-coupled amino acid transporter hPAT1. J Pharmacol Exp Ther. 309, 28-35.

Nose, S., Wasa, M., Tazuke, Y., Owari, M. \& Fukuzawa, M. 2010. Cisplatin upregulates glutamine transport in human intestinal epithelial cells: the protective mechanism of glutamine on intestinal mucosa after chemotherapy. $J$ Parenter Enteral Nutr 34, 530-7.

Rajan, D. P., Huang, W., Kekuda, R., George, R. L., Wang, J., Conway, S. J., Devoe, L. D., Leibach, F. H., Prasad, P. D. \& Ganapathy, V. 2000. Differential influence of the $4 \mathrm{~F} 2$ heavy chain and the protein related to $\mathrm{b}^{0,+}$ amino acid transport on substrate affinity of the heteromeric $\mathrm{b}^{0,+}$ amino acid transporter. J Biol Chem 275, 14331-5.

Romeo, E., Dave, M. H., Bacic, D., Ristic, Z., Camargo, S. M., Loffing, J., Wagner, C. A. \& Verrey, F. 2006. Luminal kidney and intestine SLC6 amino acid transporters of $\mathrm{B}^{0} \mathrm{AT}$-cluster and their tissue distribution in Mus musculus. Am J Physiol Renal Physiol 290, F376-83. 
Sakar, Y., Nazaret, C., Letteron, P., Ait Omar, A., Avenati, M., Viollet, B., Ducroc, R. \& Bado, A. 2009. Positive regulatory control loop between gut leptin and intestinal GLUT2/GLUT5 transporters links to hepatic metabolic functions in rodents. PLoS One 4, e7935.

Seidler, U., Rottinghaus, I., Hillesheim, J., Chen, M., Riederer, B., Krabbenhoft, A., Engelhardt, R., Wiemann, M., Wang, Z., Barone, S., Manns, M. P. \& Soleimani, M. 2008. Sodium and chloride absorptive defects in the small intestine in Slc26a6 null mice. Pflugers Arch 455, 757-66.

Shirazi-Beechey, S. P., Davies, A. G., Tebbutt, K., Dyer, J., Ellis, A., Taylor, C. J., Fairclough, P. \& Beechey, R. B. 1990 Preparation and properties of brush-border membrane vesicles from human small intestine. Gastroenterology 98, 676-85.

Souba, W. W., Pan, M. \& Stevens, B. R. 1992. Kinetics of the sodium-dependent glutamine transporter in human intestinal cell confluent monolayers. Biochem Biophys Res Commun 188, 746-53.

Than, A., Ye, F., Xue, R., Ong, J. W., Poh, C. L. \& Chen, P. 2011.The crosstalks between adipokines and catecholamines. Mol Cell Endocrinol 332, 261-70.

Thwaites, D. T., McEwan, G. T., Cook, M. J., Hirst, B. H. \& Simmons, N. L. (1993) $\mathrm{H}^{+}$-coupled $\left(\mathrm{Na}^{+}\right.$-independent) proline transport in human intestinal (Caco-2) epithelial cell monolayers. FEBS Lett 333, 78-82.

¿tsunomiya-Tate, N., Endou, H. \& Kanai, Y. 1996. Cloning and functional (Brasil) characterization of a system ASC-like $\mathrm{Na}^{+}$-dependent neutral amino acid transporter. J Biol Chem 271, 14883-90.

Zhang, Y., Proenca, R., Maffei, M., Barone, M., Leopold, L. \& Friedman, J. M. 1994. Positional cloning of the mouse obese gene and its human homologue. Nature 372, 425-32. 


\section{LEGENDS TO FIGURES}

Figure 1 Effect of leptin on MG uptake by Caco-2 cells. (a) MG (0.1 mM) uptake after 5 and 30 min incubation was measured in the absence and in the presence of 0.2 or 8 $n M$ leptin. Data $(n=47-53)$ are expressed as $\%($ mean \pm SEM) of control values $(0$ leptin). ${ }^{*} \mathrm{p}<0.05$; ${ }^{* * *} \mathrm{p}<0.001$ vs control. (b) Expression of SGLT1 protein $(75 \mathrm{kDa})$ in BBMV of Caco-2 cells obtained after 30 min incubation of the cells with $0.1 \mathrm{mM} \mathrm{MG}$ in the presence and in the absence of $8 \mathrm{nM}$ leptin. The intensity of the immunoreactive bands (transporter/ $\beta$-actin) is expressed in $\%$ of control $(M G) n=3$. A representative Western blot image is also represented. ${ }^{* *} \mathrm{p}<0.01$ vs MG. (c) Effect of leptin and the PKA inhibitor H-89 on MG uptake. After 30 min pre-incubation of the cells without or with $1 \mu \mathrm{M} \mathrm{H}-89,0.1 \mathrm{mM}$ MG patake (30 min) was measured in the absence of leptin (control; H-89) and in the presence of the hormone at $8 \mathrm{nM}$ (leptin; leptin+H-89). Data $(\mathrm{n}=12-48)$ are expressed as $\%$ (mean $\pm \mathrm{SEM})$ of control uptake. ${ }^{* * *} \mathrm{p}<0.001$ vs. control.

Figure 2 Effect of leptin on Gln and Phe uptake by Caco-2 cells. Uptake of $0.1 \mathrm{mM}$ Gln (a) or $0.1 \mathrm{mM}$ Phe (c) was measured in the absence and in the presence of 0.2 and $8 \mathrm{nM}$ leptin in $\mathrm{Na}^{+}$buffer after 5 and 30 min incubation. We took advantage of the distinct affinity of Gln transporters (ASCT2 micromolar and $\mathrm{B}^{0} \mathrm{AT} 1$ millimolar range) to discriminate putative transporters affected by leptin in substrate competition experiments (b). Uptake of $20 \mu \mathrm{M}$ Gln was thus determined in the presence of $8 \mathrm{nM}$ leptin and $25 \mathrm{mM}$ Phe at $30 \mathrm{~min}$ incubation. (d) Uptake of $0.1 \mathrm{mM}$ Gln was measured for $30 \mathrm{~min}$ in the presence and absence of $8 \mathrm{nM}$ leptin in $\mathrm{Na}^{+}$buffer and $\mathrm{Na}^{+}$-free buffer 
(D). Data in each graphic $(n=13-38)$ are expressed as $\%$ (mean \pm SEM) of control uptake (0 leptin, $\left.+\mathrm{Na}^{+}\right) .{ }^{*} \mathrm{p}<0.05 ; * * \mathrm{p}<0.01 ; * * * \mathrm{p}<0.001$ vs control.

Figure 3 (a) Expression of ASCT2 ( 60 kDa) and $\mathrm{B}^{0} \mathrm{AT} 1(\sim 60 \mathrm{kDa})$ protein in BBMV of Caco-2 cells. BBMV were obtained after 30 min incubation of the cells with $0.1 \mathrm{mM}$ Gln in the presence and in the absence of $8 \mathrm{nM}$ leptin. The intensity of the immunoreactive bands (transporter/ $\beta$-actin) is expressed in $\%$ of control (Gln; $n=3)$. A representative Western blot image is also represented. * $\mathrm{p}<0.05$; ${ }^{* *} \mathrm{p}<0.01$ vs Gln. (b) Effect of leptin and the PKA inhibitor H-89 on Gln uptake. After 30 min pre-incubation of the cells without or with $1 \mu \mathrm{M} \mathrm{H}-89,0.1 \mathrm{mM}$ Gln uptake (30 min) was measured in the absence of leptin (control; $\mathrm{H}-89$ ) or in the presence of the hormone at $8 \mathrm{nM}$ (leptin; leptin $+H-89)$. Data $(n=12-36)$ are expressed as $\%\left(\right.$ mean \pm SEM) of control. ${ }^{* *} \mathrm{p}<0.01$; *** $\mathrm{p}<0.001 ;$ vs control; \#\# $\mathrm{p}<0.01$ vs leptin.

Figure 4 Effect of leptin on Pro and $\beta$-Ala uptake by Caco-2 cells. (a) Uptake of $1 \mathrm{mM}$ Pro was first measured in $\mathrm{Na}^{+}$-free medium $\left(-\mathrm{Na}^{+}\right)$and in $\mathrm{Na}^{+}$medium $\left(+\mathrm{Na}^{+}\right)$at $\mathrm{pH} 7.5$ and $\mathrm{pH} 6(\mathrm{n}=20-30)$. Uptake of $1 \mathrm{mM}$ Pro (b) or $\beta$-Ala (c) at $\mathrm{pH} 6$ in $\mathrm{Na}^{+}$medium was measured in the absence and in the presence of 0.2 and $8 \mathrm{nM}$ leptin, after 5 and $30 \mathrm{~min}$ incubation. Data in $\mathrm{b}$ and $\mathrm{c}(\mathrm{n}=20-33)$ are expressed as $\%$ (mean \pm SEM) of control value (0 leptin). ${ }^{*} \mathrm{p}<0.05 ;{ }^{* *} \mathrm{p}<0.01 ;{ }^{* * *} \mathrm{p}<0.001$ vs $\mathrm{pH} 7.5$ (A) or control (B, C); \# $\mathrm{p}<$ $0.05 ; \# \# \mathrm{p}<0.01 \mathrm{vs} \mathrm{Na}^{+}$-free medium. Control values for Pro uptake in $\mathrm{b}$ were $1.1 \pm 0.05$ and $2.05 \pm 0.66 \mathrm{nmol} \mathrm{mg}^{-1}$ of protein at 5 and 30 min respectively. Control values for $\beta$ Ala uptake in c were $0.37 \pm 0.02$ and $2.05 \pm 0.66 \mathrm{nmol} \mathrm{mg}^{-1}$ of protein at 5 and $30 \mathrm{~min}$ respectively. 
Figure 5 (a) Effect of leptin on PAT1 protein expression in BBMV of Caco-2 cells. BBMV were obtained after 30 min incubation with $1 \mathrm{mM} \beta$-Ala in the absence and in the presence of $8 \mathrm{nM}$ leptin (a). The intensity of the $\sim 50 \mathrm{kDa}$ immunoreactive bands (transporter $/ \beta$-actin) is expressed in $\%$ of control $(\beta$-Ala; $n=4)$. A representative Western blot image is also represented. (b) Effect of leptin and the PKA inhibitor H-89 on $\beta$-Ala uptake. After 30 min pre-incubation of the cells without or with $1 \mu \mathrm{M} \mathrm{H}-89,0.1 \mathrm{mM}$ Gln uptake (30 min) was measured in the absence of leptin (control; H-89) and in the presence of the hormone at $8 \mathrm{nM}$ (leptin; leptin $+\mathrm{H}-89$ ). (c) Uptake of $1 \mathrm{mM} \beta$-Ala in the absence and in the presence of $8 \mathrm{nM}$ leptin after 30 min in $\mathrm{Na}^{+}$buffer $\left(+\mathrm{Na}^{+}\right)$and $\mathrm{Na}^{+}-$ free buffer $\left(-\mathrm{Na}^{+}\right)$. Data in each graphic $(\mathrm{n}=6-32)$ are expressed as $\%($ mean $\pm \mathrm{SEM})$ of control value $\left(\mathrm{Na}^{+}\right) .{ }^{*} \mathrm{p}<0.05 ; * * \mathrm{p}<0.01$ vs; $* * * \mathrm{p}<0.001$ vs control; \#\#\# $\mathrm{p}<0.001$ vs leptin. 